\title{
Ethnobotanical survey on plants used in the treatment of candidiasis in traditional markets of southern Benin
}

Brice Armand Fanou ${ }^{1}$, Jean Robert Klotoe ${ }^{1,2^{*}}$ D, Lauris Fah", Victorien Dougnon ${ }^{1}$, Charles Hornel Koudokpon ${ }^{1}$, Ghislaine Toko $^{3}$ and Frédéric Loko ${ }^{1}$

\begin{abstract}
Background: Candidiasis, an opportunistic cosmopolitan disease is nowadays like bacterial infections which is a real public health problem. In view of the emergence of Candida strains resistant to existing antifungal agents, alternative solutions should be considered. This is the purpose of this ethnobotanical survey, which aims to identify the medicinal plant species traditionally used to treat candidiasis in traditional markets of southern Benin.

Methods: The study was performed from October 2015 to January 2018 in the traditional markets of SouthernBenin. Data were collected by two complementary methods: triplet purchase of medicinal recipes (ATRM) from herbalists markets and semi-structured interview (ISS) from traditional healers.

Results: A total of 109 species of medicinal plants belonging to 44 families have been listed and identified. The most frequently cited species were Pteleopsis suberosa Engl. \& Diels, Lantana camara L., Cyanthillium cinereum (L.) H. Rob, Ocimum gratissimum L. and Lippia multiflora Moldenke with respectively 43.84, 39.73 and 34.25\% citation frequencies for the last three species respectively. Leguminosae (20.18\%), Euphorbiaceae (5.50\%) and Apocynaceae (5.50\%) were the most represented botanical families. Leafy stems were more used than other plant organs. The decoction and the oral route were the most appropriate methods of preparation and administration reported by traditional healers.
\end{abstract}

Conclusion: Benin's plant cover is made up of a wide variety of medicinal plant species used in the traditionnal treatment of candidiasis and which may constitute new sources of medicines to be developed.

Keywords: Candidiasis, Ethnobotanical survey, Medicinal plants, Southern Benin

\footnotetext{
* Correspondence: jrklotoe@yahoo.fr

'Unité de Recherche en Microbiologie Appliquée et Pharmacologie des substances naturelles (URMAPha), Laboratoire de Recherche en Biologie Appliquée (LARBA), Ecole Polytechnique d'Abomey-Calavi (EPAC), Université d'Abomey-Calavi, 01BP2009 Cotonou, Bénin

${ }^{2}$ Ecole Normale Supérieure de Natitingou, Université Nationale des Sciences, Technologie, Ingénierie et Mathématiques, BP72 Natitingou, Benin Full list of author information is available at the end of the article
}

(c) The Author(s). 2020 Open Access This article is licensed under a Creative Commons Attribution 4.0 International License, which permits use, sharing, adaptation, distribution and reproduction in any medium or format, as long as you give appropriate credit to the original author(s) and the source, provide a link to the Creative Commons licence, and indicate if changes were made. The images or other third party material in this article are included in the article's Creative Commons licence, unless indicated otherwise in a credit line to the material. If material is not included in the article's Creative Commons licence and your intended use is not permitted by statutory regulation or exceeds the permitted use, you will need to obtain permission directly from the copyright holder. To view a copy of this licence, visit http://creativecommons.org/licenses/by/4.0/. The Creative Commons Public Domain Dedication waiver (http://creativecommons.org/publicdomain/zero/1.0/) applies to the data made available in this article, unless otherwise stated in a credit line to the data. 


\section{Background}

Candidiasis is a cosmopolitan fungal infection associated with yeasts of the genus Candida. It is one of the most common opportunistic infections in tropical areas, with a frequency ranging from 33 to $47 \%$ in [1]. In recent decades, their prevalence has been steadily increasing, especially among patients in intensive care and with the advent of HIV/AIDS infection [1-3]. They affect all types of tissues and mainly mucous membranes [4-6]. It is reported that $25 \%$ of urinary tract infections were related to Candida spp. [7]. 50 to $75 \%$ of women of childbearing age developed vulvovaginal candidiasis annually and 5 to $8 \%$, or about 75 million women, can be affected at least four times in a year [8-10]. Oral infections are common but are found in children and immune compromised people [11]. Ten million cases of oral candidiasis and 2 million esophageal candidiasis are reported annually in people living with HIV. Most seriously, invasive fungal infections are reported to kill more than tuberculosis and malaria and in 90\% of fungal deaths, candidiasis ranks second behind cryptococcosis and ahead of aspergillosis and pneumocystis [12-14]. They are fatal in $40 \%$ of hospital sepsis cases according to letter No. 72 from the Pasteur Institute [15] and are the leading nosocomial fungal disease [9, 16, 17]. Their therapeutic management requires the use of antifungals to which Candida spp. strains are increasingly resistant $[7,18,19]$. Indeed, high levels of Candida spp. resistance to fluconazole have been identified in several countries [20-22]. Candida spp. resistance even extends to amphotericin B [23], one of the last used antifungals [24, 25]. This emergence of strains resistant to common molecules is, like the emergence of bacterial resistance to antibiotics, of a great public health concern for which sustainable alternative solutions must be found very quickly. In African countries, these alternative solutions involve the use of medicinal plants. Indeed, the use of plants to treat diseases is an old practice [26-29] and endogenous to populations. According to several authors, in Africa and Asia, $80 \%$ of the population continues to use traditional medicines rather than the socalled modern medicines for primary health care for various reasons [30-32]. Today, with the support of WHO [33], many research focuses on plants to look for active compounds [3, 34-36]. In this sense, some research carried out on plants has shown in vitro their antifungal potential [37-40] and could thus constitute new sources of bioactive molecules [31, 41].

Unfortunately, plant resources are under significant anthropogenic pressure which dangerously reduces plant biodiversity. According to Djégo et al., Benin loses 60, 000 ha of forest per year, an annual rate of deforestation estimated at $1.2 \%$. This deforestation is not without consequences for conservation on medicinal plants. Several medicinal species have thus disappeared or are threatened with extinction. It is therefore important to ensure their conservation for the next generations. This requires their knowledge and compliance with the rules of sustainable use [42].

In Benin, the plant species indicated for candidiasis treatment is still poorly known, because few studies have been carried out on the antifungal properties of some medicinal plants [43]. This work is therefore the first on aiming to identify the medicinal plants indicated by herbalists and traditional healers in southern Benin for the treatment of candidiasis.

\section{Methods}

Framework

The surveys were conducted in Benin from October 2015 to January 2017, in the geographical area between longitude $03^{\circ} 40^{\prime}$ and $04^{\circ} 11^{\prime}$ north and the $09^{\circ} 16^{\prime}$ $09^{\circ} 52^{\prime}$ east meridians. It is bordered to the north by Bassila and Tchaourou municipalities (departments of Borgou and Donga), to the west by Togo, to the east by Nigeria and to the south by the Atlantic Ocean (Fig. 1). It covers eight of the twelve departments in the Republic of Benin and corresponds to thirty-six (36) municipalities out of the forty-one in the southern part of Benin.

The localities concerned by study are:

- Cotonou (09 traditional markets: Agla, Akpakpa, Dantokpa, Fifadji, Fidjrossè, Gbèdjromèdé, Gbogbanou, Mènontin, Wologuèdè)

- Abomey-Calavi (04 traditional markets: Atrokpocodji, Godomey, Tokan, Tokpa)

- Porto-Novo (02 traditional markets: Ahidahomè, Ouando)

- Abomey (01 traditional market: Houndjro)

- Adjara (01 traditional market: Adjarra)

- Azovè (01 traditional market: Azovèhi)

- Bohicon (01 traditional market: Gbohicon)

- Covè (01 traditional market: Covèhi)

- Dassa-Zoumè (01 traditional market: Dassa)

- Dogbo-Tota (01 traditional market: Dogbo)

- Klouékanmey (01 traditional market: Klouékanmè)

- Lokossa (01 traditional market: Lokossahimè)

- Ouidah (01 traditional market: Kpassè)

- Savalou (01 traditional market: Savalouhi)

- Savè (01 traditional market: Savè)

- Tori (01 traditional market: Gbodjè).

\section{Equipment}

Equipment used in this study consists mainly of survey sheets for information collection, a digital camera, a selfrecording audio device for interview recording, a position marker (GPRS). 


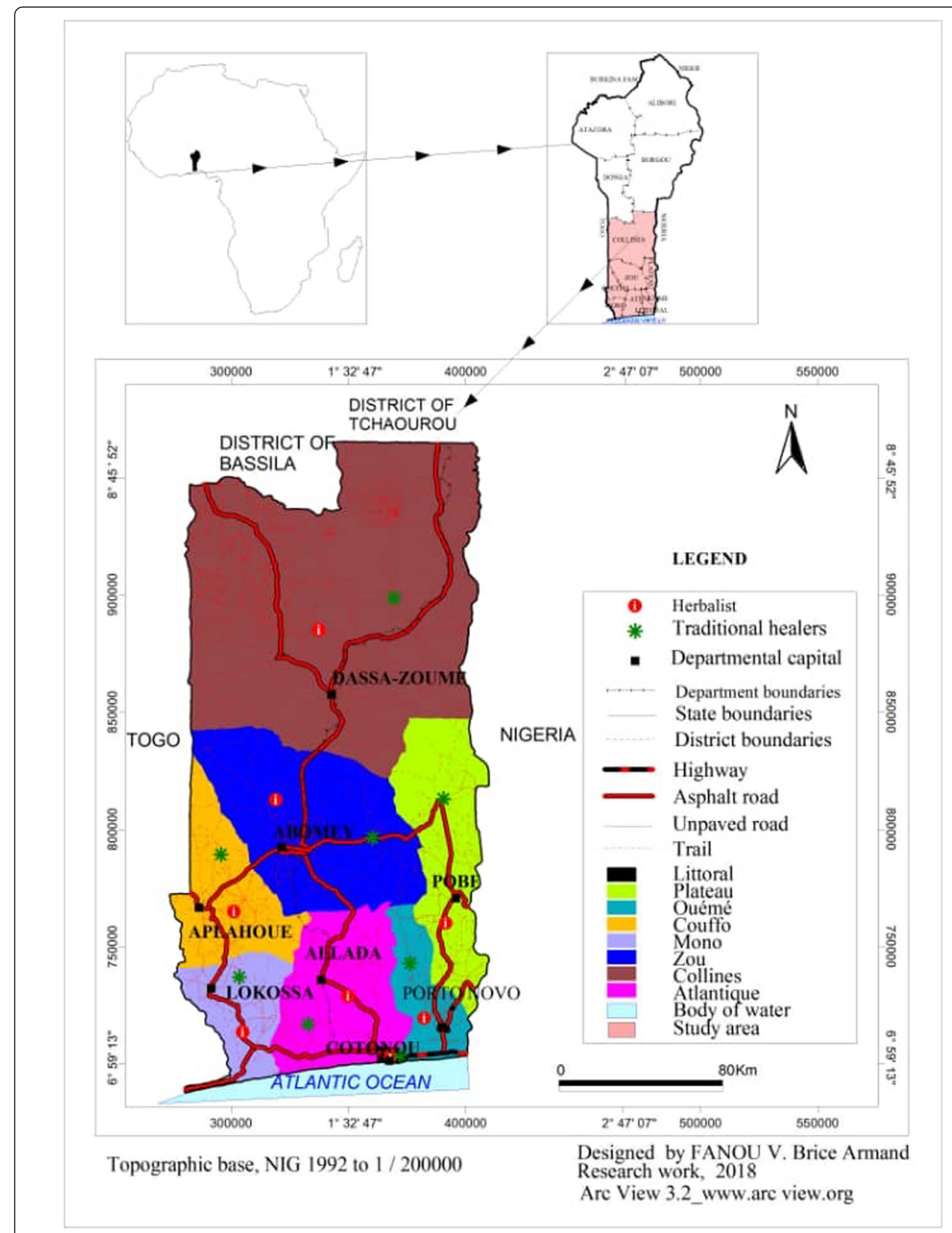

Fig. 1 Location of traditional markets covered by the ethnobotanical survey 


\section{Methods}

The surveys were conducted with two groups of professionals: market herbalists and traditional healers. Market herbalists sell herbal remedies and also compose recipes for the treatment of illnesses. They don't directly treat patients. This role is reserved for traditional healers. The traditional healers interviewed are recognized by the $\mathrm{Na}$ tional Program for the Promotion of Traditional Medicine in Benin. As for herbalists, they are registered with the market management company.

Two (02) methods were used for each group of informants. Thus, among market herbalists, the triplet purchase of medicinal recipes (ATRM) method was used and the semi-structured interview method (ISS) was used among traditional healers [44-47].

Interviews were conducted in three local languages (Fon, Goun or Mina) and then in French for those who were literate. An interpreter was recruited from each location where local language spoken was not understand.

Data collected consisted of the socio-demographic characteristics of the respondents (sex, age, professional experience, mode of entry into the profession) and information on the recipes used to treat candidiasis (composition of recipes, local names and parts of plants used, methods of preparation and administration routes of the recipes served, dosage, bans and side effects). The study focused on cutaneous candidiasis "Atita"; oral candidiasis "Noumè vo", genital candidiasis or vulvovaginitis "Atita do Gnonnnou houé". Pictures of the recipes and plants mentioned were taken and sampled. Herbariums were then created for taxonomic identification (scientific name, family).

\section{Identification of plant species}

The species mentioned by the markets herbalist were purchased and those indicated by the traditional healers were harvested. Each time, care was taken to collect or purchase fresh samples for identification. These collected samples were identified at the National Herbarium of Benin of the University of Abomey-Calavi (UAC-Benin) using the analytical flora of Benin by Akoègninou et al. [48]. The botanical nomenclature used is that of the "The Plant List" database available on the website www.theplantlist.org.

Listed plant species were checked against the IUCN Red List Categories (Critically Endangered, Endangered, Vulnerable, Near Threatened) to identify endangered species.

\section{Data analysis}

The data collected were processed using Microsoft Excel version 2010 software, which was also used to draw graphs (Pie charts, charts and histograms). The variables were presented in percentage.

The phototherapeutic importance of each species was assessed by calculating four parameters, namely:
- The informant fidelity index (FI)

$F I=\frac{\mathrm{Nc}}{\mathrm{Nt}} x 100 \quad(\mathrm{Nc}=$ number of informants in a given category who cited the species; $\mathrm{Nt}=$ total number of informants in all categories who cited the same species).

It makes it possible to assess the relationship between a given plant species and its use by herbalists and/or traditional healers in the treatment of candidiasis $[49,50]$.

- The Informant Consensus Factor (ICF) calculated by the formula (total number of revenues minus total number of informants / total number of revenues minus 1$)[49,51,52]$. This consensus factor of informants here expresses their "approval rate" in related to the plants used to make the recipes for candidiasis treatment. The value of the ICF is less than or equal to 1 , so when the value of the ICF is less than 0.5 , the consensus is low, when it is between 0.5 and 0.75 the consensus is high and very high when the ICF tends towards 1 .

- The citation frequency (Fc) expressed as a percentage (\%) and obtained by the formula: (number of citations of a species / total number of citations of species) $\times 100[53,54]$.

- The contribution of each plant species to recipes composition (Cpr) expressed as a percentage (\%). It is also the frequency with which plants are involved in recipes. It was calculated by the formula (number of recipes using the plant species / total number of recipes $) \times 100(55)$.

\section{Results}

\section{Sociodemographic characteristics of responders}

The recipes were provided by seventy-three (73) informants, fifty-one (51) market herbalists and twenty-two (22) traditional healers with an average age of $52 \pm 14.65$ years. All the traditional healers were men and the market herbalists were women. The average ages of traditional healers and herbalists were $53.54 \pm 14.79$ years and $51.31 \pm 14.63$ years respectively, with 40 to 60 years as predominant age group (Table 1). The majority (90\%) of informants were experienced in this activity for at least ten years. And more than half of them (63\%) had more than twenty years' experience (Fig. 2) but traditional healers seem to be less experienced than market herbalists. Two thirds (67\%) of the responders were out of school. However, the traditional healers sub-group has more educated people than the market herbalists (Fig. 3).

\section{Inventory of recipes and plant species}

A total of 124 recipes were provided, 81 (65\%) of which were from market herbalists. Table 2 gives the 
Table 1 Age distribution of respondents

\begin{tabular}{llll}
\hline Age groups (years) & Herbalists $\mathbf{n}$ (Frequency in \%) & Traditional healers $\mathbf{n}$ (Frequency in \%) & Overall $\mathbf{n}$ (Frequency in \%) \\
\hline Below 20 & $0(\mathbf{0} \%)$ & $0(0 \%)$ & $0(0 \%)$ \\
{$[20-40[$} & $9(\mathbf{1 7 . 6 5 \% )}$ & $3(\mathbf{1 3 . 6 4 \% )}$ & $12(\mathbf{1 6 . 4 4 \% )}$ \\
{$[40-60[$} & $26(\mathbf{5 0 . 9 8 \% )}$ & $12(\mathbf{5 4 . 5 4 \% )}$ & $38(\mathbf{5 2 . 0 5 \% )}$ \\
60 and more & $16(\mathbf{3 1 . 3 7 \% )}$ & $7(\mathbf{3 1 . 8 2} \%)$ & $23(\mathbf{3 1 . 5 1 \% )}$ \\
Total & $51(100.00 \%)$ & $22(100.00 \%)$ & $73(100 \%)$ \\
\hline
\end{tabular}

composition of the recipes served. The recipes are made up of a single plant species $(21.77 \%)$ or a combination of plants species (78.23\%). The number of plants per recipe varied according to the category of informants. It was obvious that the proportion of plants constituting the recipes for market herbalists was in opposite trend compared to that of traditional healers. Indeed, plant associations were much more noticeable among herbalists with $45.68 \%$ of recipes composed of more than 6 plant species compared to only $6.98 \%$ among traditional healers. It should be noted that in some cases (6.45\%) non-plant elements such as mineral compound (kaolin, alum or salt) and sulphur are added to plant organs in the composition of recipes.

The high proportion of recipes provided by herbalists could have a pecuniary cause. Indeed, since the recipes were bought from herbalists and the cost of a recipe varies most of the time between 300f CFA for the cheapest and 500f CFA or even 1200f CFA for the most expensive, the herbalists prefer to pay for the same affection all that they know as recipes.

The most used preparation method is decoction (82\%). Only traditional healers talked about maceration, corresponding to only $2.45 \%$ of recipe preparation methods (Fig. 4). The oral route was the most indicated route $(45.16 \%)$ by informants for preparation administering (Fig. 5).

The floristic inventory of species identified 109 species of 101 genera and divided into 44 botanical families (Table 3) with an overall ICF consensus index of 0.12.

The most represented families were Leguminosae (20.18\%) followed by Euphorbiaceae (5.50\%), Apocynaceae $(5.50 \%)$, poaceae $(4.59 \%)$ and Combretaceae (4.59\%) (Fig. 6).

The most frequently cited species were Pteleopsis suberosa Engl. \& Diels, Lantana camara L., Cyanthillium cinereum (L.) H. Rob, Ocimum gratissimum L. and Lippia multiflora Moldenke with respectively 29.36, 26.61 and $22.94 \%$ citation frequencies respectively. The most frequently mentioned species did not necessarily belong in order to the most represented botanical families. Their respective frequencies of involvement in the composition of the recipes (Cpr) were 25.81, 23.39, 20.00, 20.00 and $20.00 \%$ respectively and their pairs of relative loyalty indices (herbalists/Traditional healers) were

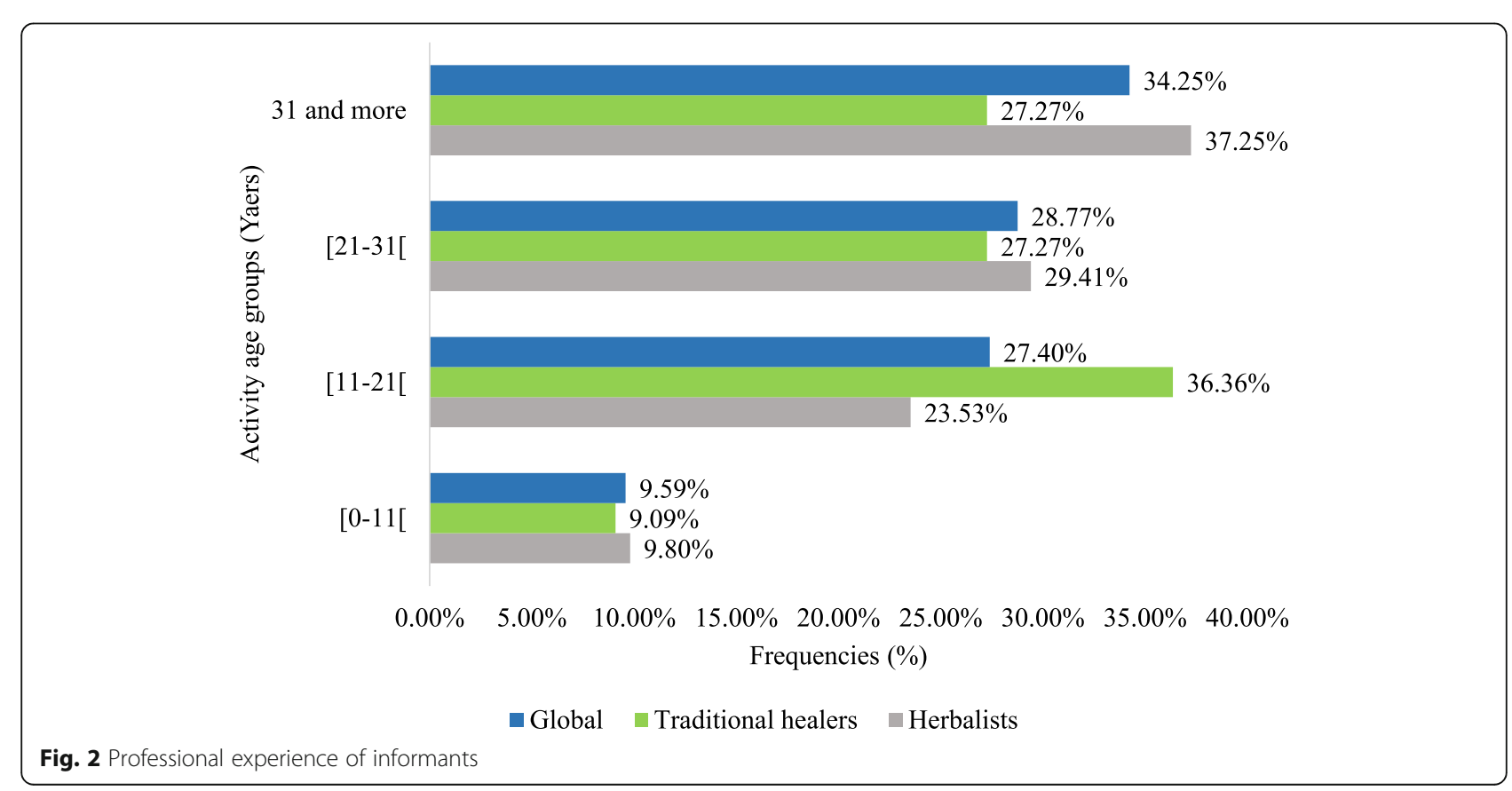




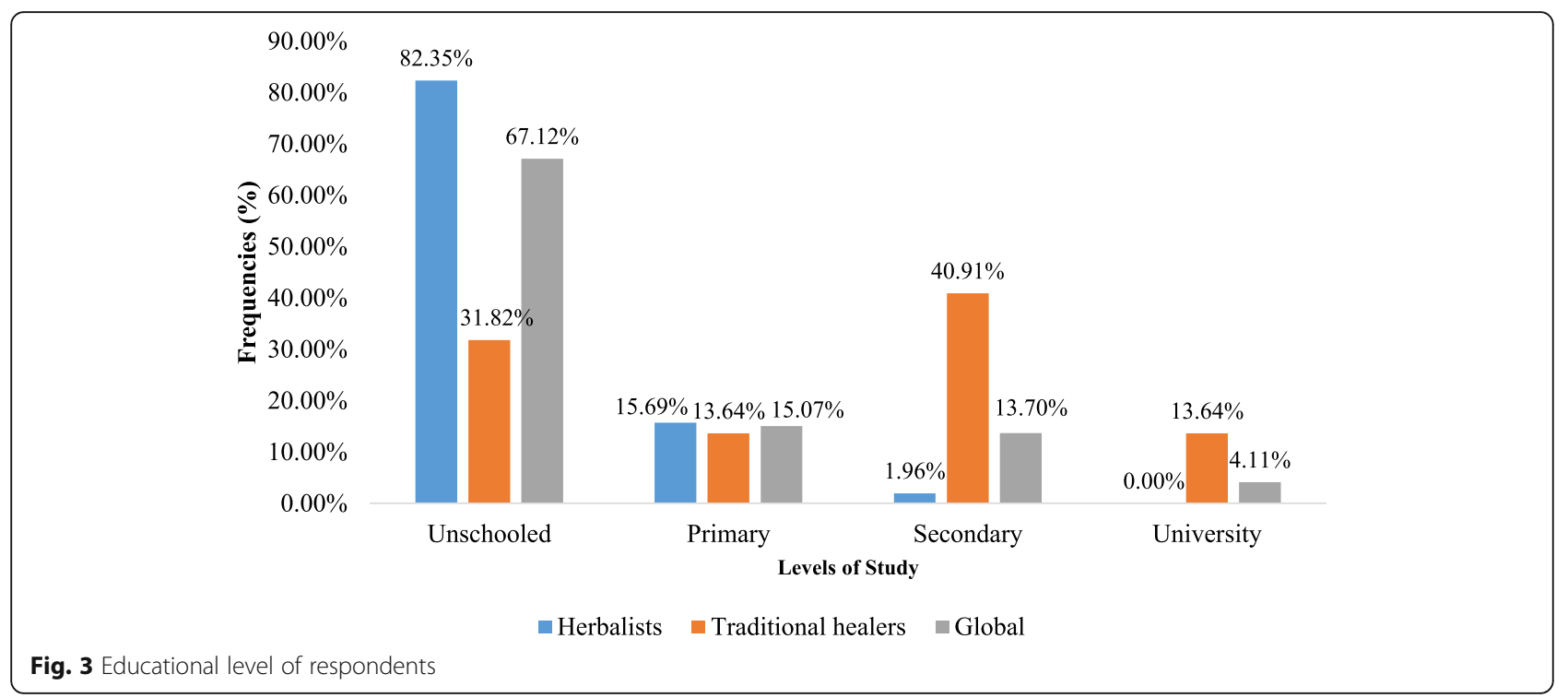

(93.75\%; 6.25\%), (89.66\%; 10.34\%), (100.00\%; 00.00\%), $(68.00 \% ; 32.00 \%)$ and $(96.00 \% ; 4.00 \%)$ respectively. Among these species, Ocimum gratissimum L. was the only plant strongly cited by both market herbalists $(66,67 \%)$ and traditional healers $(33,33 \%)$ and involved in about $20 \%$ of the recipes provided (Table 3). Also, it should be noted that even if Cyanthillium cinereum (L.) H. Rob and Lippia multiflora Moldenke seem to be two species widely used by herbalists, traditional healers did not use them so frequently.

In addition, seven (07) species of plants inventoried in this study are on the IUCN Red List as Near Threatened (Cajanus cajan (L.) Millsp., Eucalyptus camaldulensis Dehnh.); Vulnerable (Afzelia Africana Pers., Garcinia kola Heckel, Gossypium hirsutum L., Khaya senegalensis (Desr.) A. Juss.); and Endangered (Pterocarpus erinaceus Poir.).

Different plant organs are used to treat different candidiasis. At the end of this survey, eight (08) plant organs were involved in the composition of traditional recipes (Fig. 7). Leafy stems (44.53\%) were the most commonly used, followed by whole plants (15.74\%) and bark (15.55\%). Roots have only a minor role $(7.87 \%)$ in recipes against candidiasis. Indeed, leafy stems and/or leaves are very important in medicinal recipes since they would constitute the basis for the synthesis of the majority of phytochemical compounds.

\section{Discussion}

The knowledge of the plants used in the treatment of candidiasis is at the level of the elderly. Indeed, in Benin as elsewhere, endogenous knowledge is often hold by elder or wise people. Thus, properties of medicinal plants are ancestral knowledge that is only transmitted from one generation to another $[60,61]$. Other surveys conducted in practitioners Africa on endogenous care practices yielded some findings comparable to ours. In addition, the high degree of seniority of traditional in this care counsellor has also been reported in surveys dealing with medicinal plants $[50,62]$. In this sense, As Zougagh et al. [50], others authors argued that deep knowledge on the use of plants for healing purposes could only be acquired after years of practice $[63,64]$.

The female predominance of market herbalists and male predominance of traditional healers observed in this study could be explained by the fact that in Benin, sales at the market is an activity mainly carried out by women. Surveys on the traditional use of plants against infections carried out in Benin in the same geographical area support our results [42, 45, 65]. Similar findings were obtained in research activities carried out in other African area highlighting the female-biased sales from the age group of 40 years and over $[64,66]$. However, in

Table 2 Composition of recipes

\begin{tabular}{lllllll}
\hline & \multicolumn{1}{l}{$\mathbf{n}$ (Frequency in \%) } & & & \\
\cline { 2 - 7 } & Single plants & Plants + NPE & 1Plant & 2plants & 3 to 5plants & 6plants and more \\
\hline Herbalists & $80(98.77 \%)$ & $1(1.23 \%)$ & $10(12.35 \%)$ & $11(13.58 \%)$ & $23(28.40 \%)$ & $37(45.68 \%)$ \\
Traditional healers & $36(83.72 \%)$ & $7(16.28 \%)$ & $17(30.23 \%)$ & $16(37.21 \%)$ & $7(16.28 \%)$ & $3(6.98 \%)$ \\
Global & $116(93.55 \%)$ & $8(6.45 \%)$ & $23(21.77 \%)$ & $27(21.77 \%)$ & $30(24.19 \%)$ & $40(32.26 \%)$ \\
\hline
\end{tabular}

NPE non-plant elements (Kaolin, alum, sulphur) 


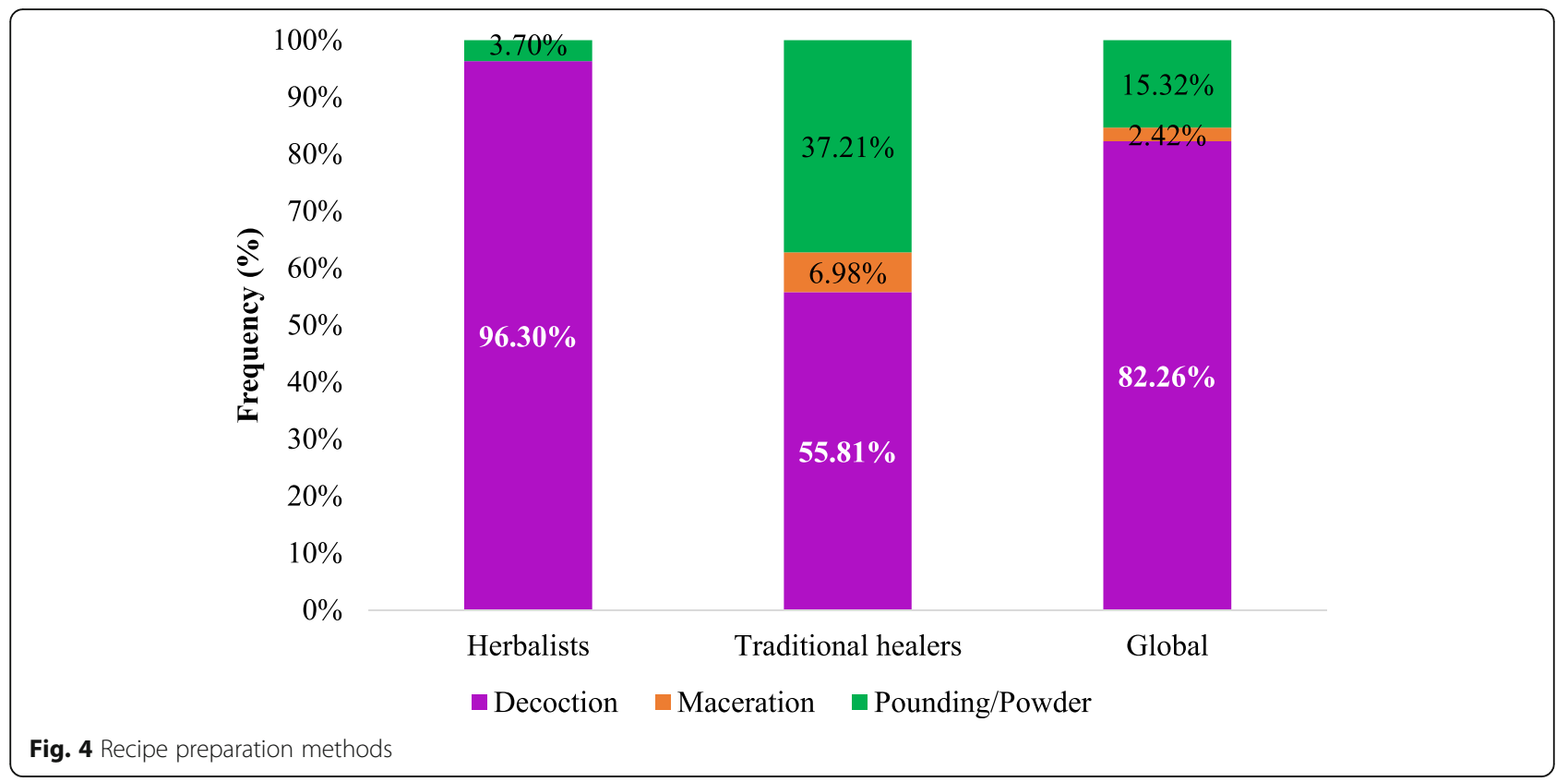

other parts of Africa, such as Morocco, the sale of medicinal plants is an activity exclusively done by men [50]. On the other hand, all the traditional healers in the current study were male, unlike the results reported by Klotoé et al. (2013) where both sexes were represented with a male predominance [44].

The responders (men/women) in our study were mostly illiterate. Our results concordance with those of other authors working in South Benin [44, 67, 68] with focus on the education rate among traditional healers (68.19\%) compared to market herbalists (17.65\%). But, unlike our study, Koudokpon et al. (2017) had only illiterate market herbalists [68]. Differences observed in our study could be due to the fact that our study dealt with almost the whole southern part of Benin and took into account more traditional healers than theirs, which was limited to two cities.

Regarding plant recipes, Klotoé et al. (2018) in their investigations of anti-hemorrhage plants found as in this study, that recipes based on medicinal plants provided by traditional healers contain mineral compounds [69]. The addition of mineral compounds to some compositions

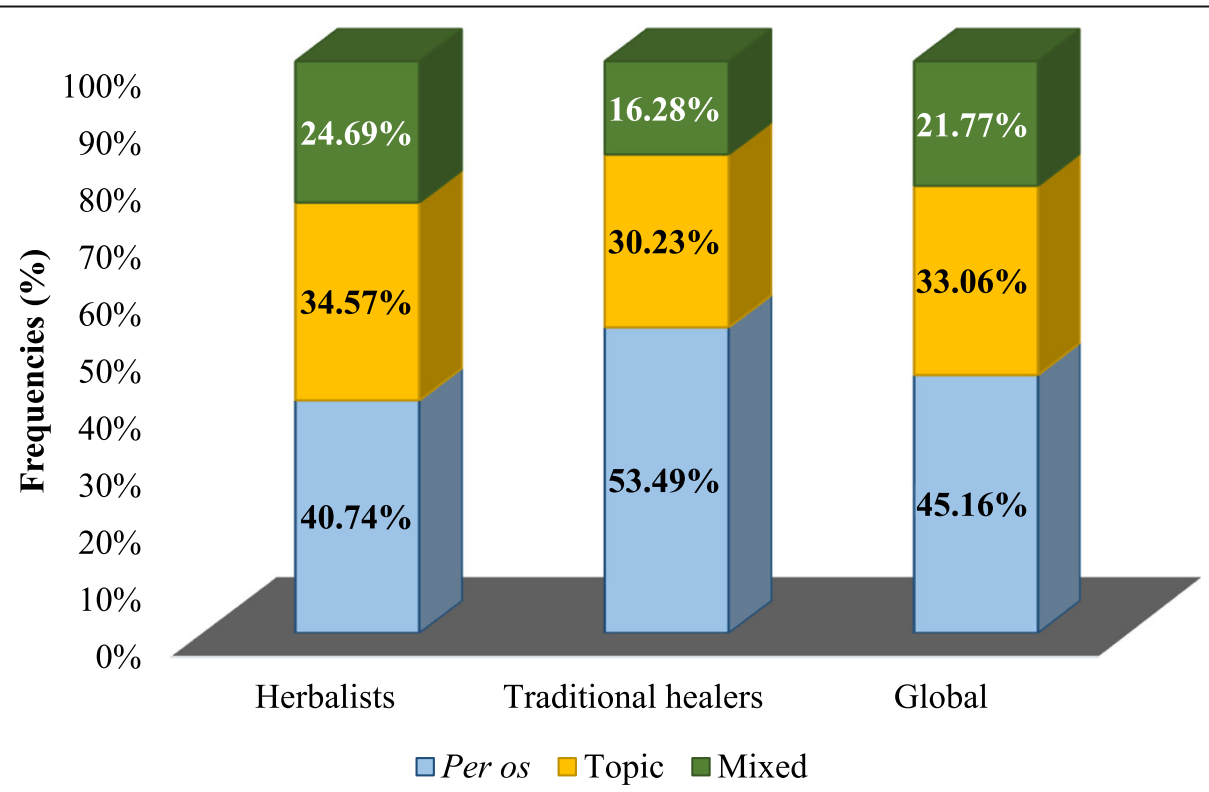

Fig. 5 Administration modes of preparation 


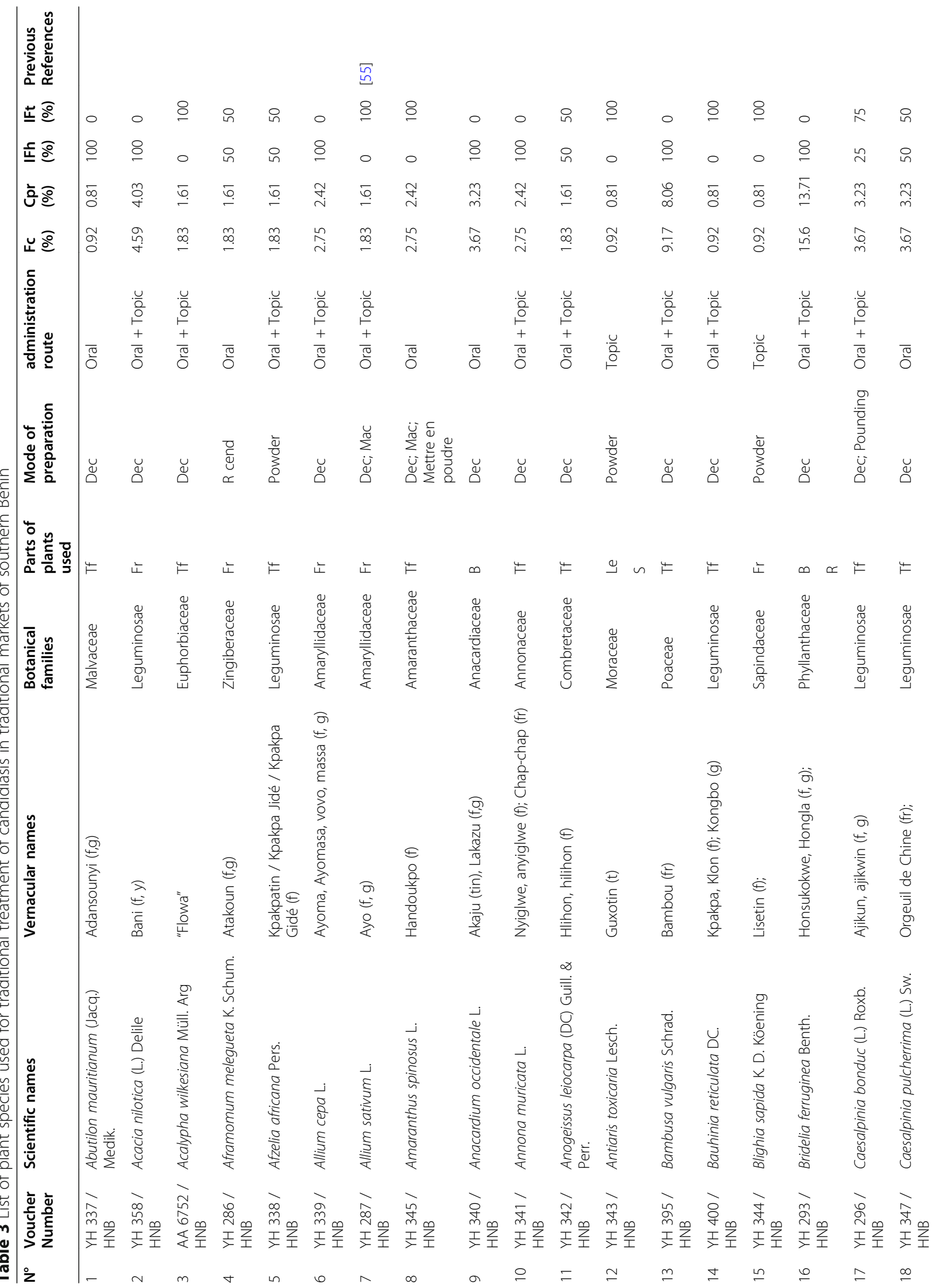




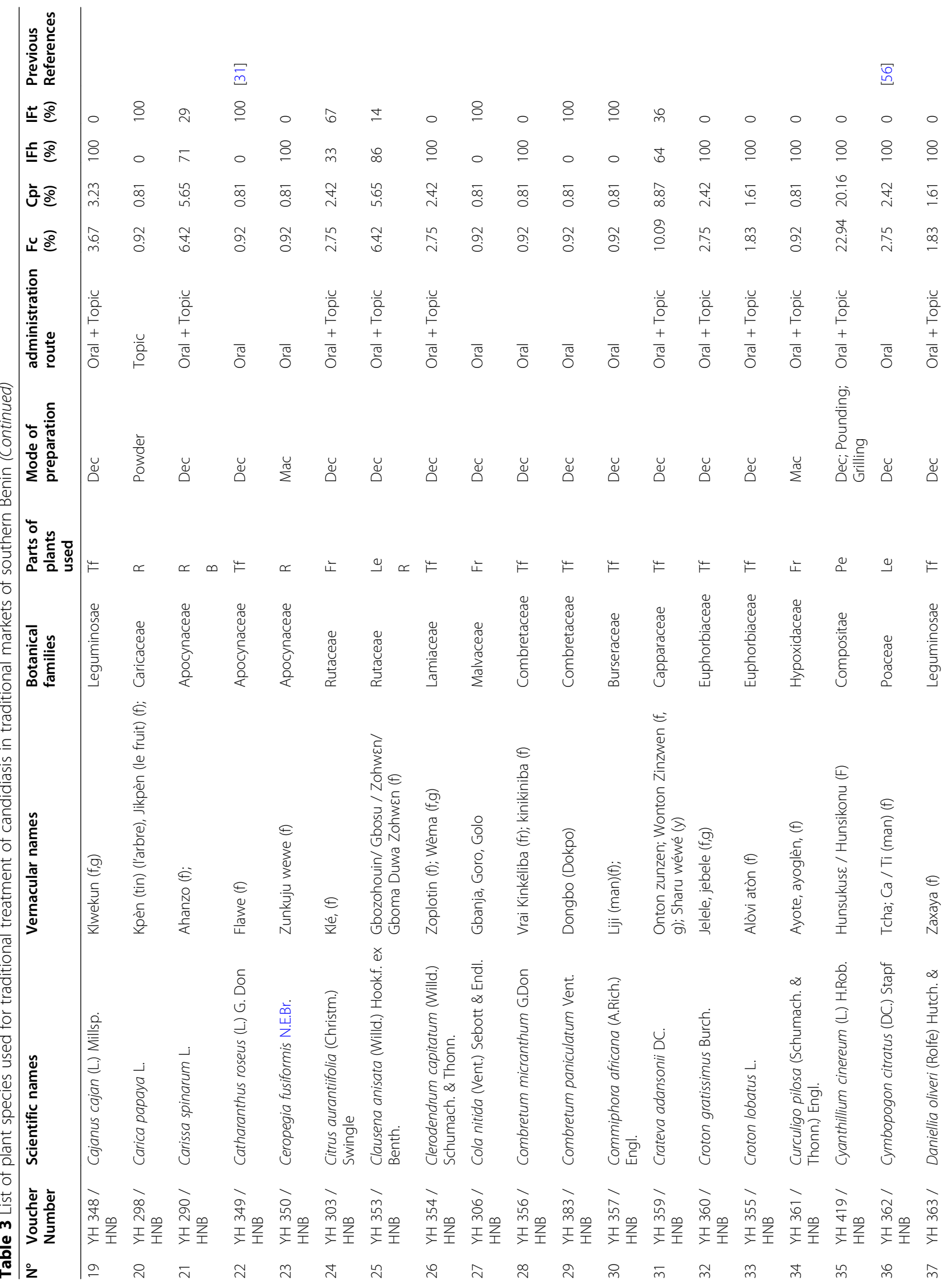




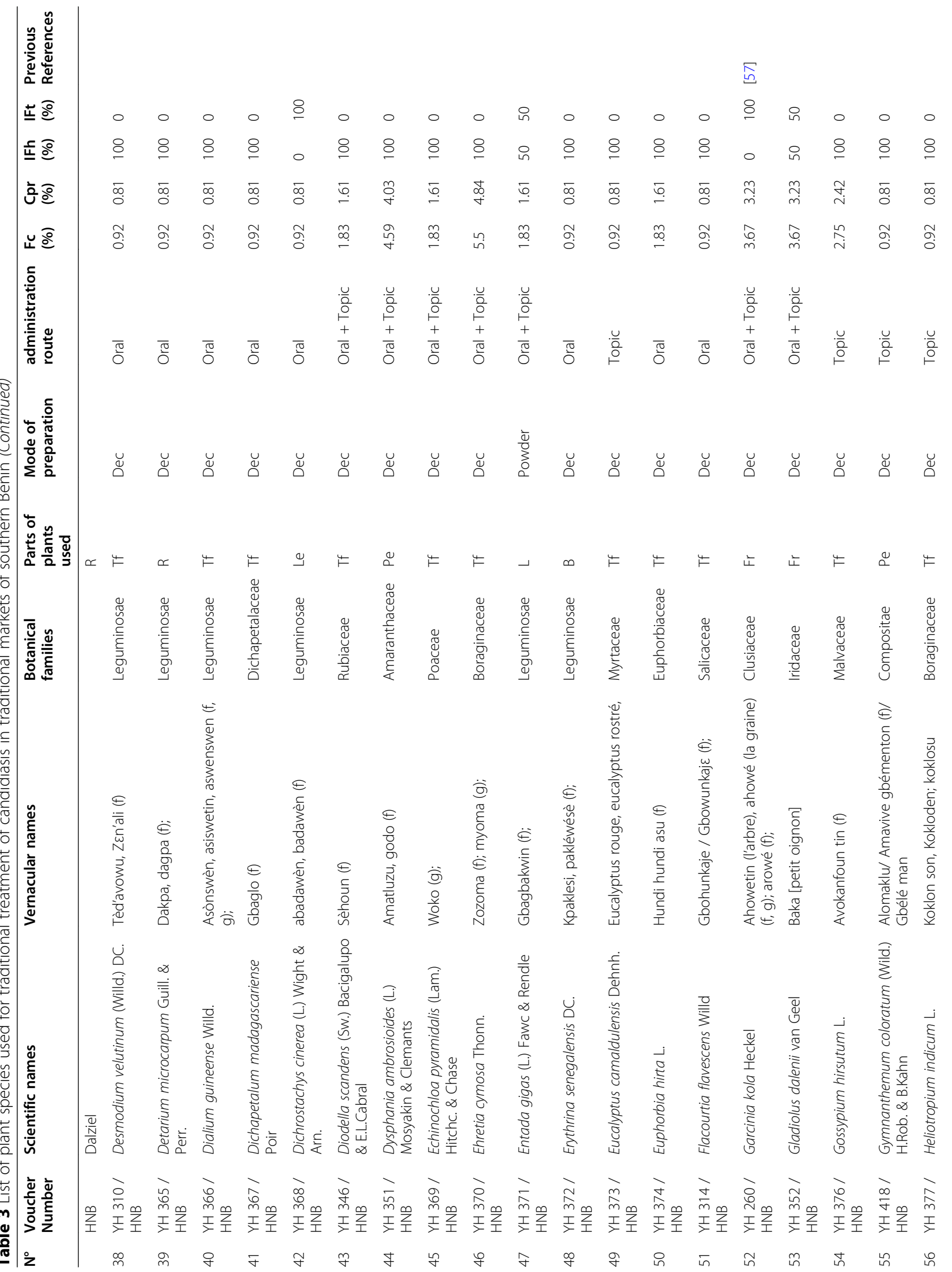




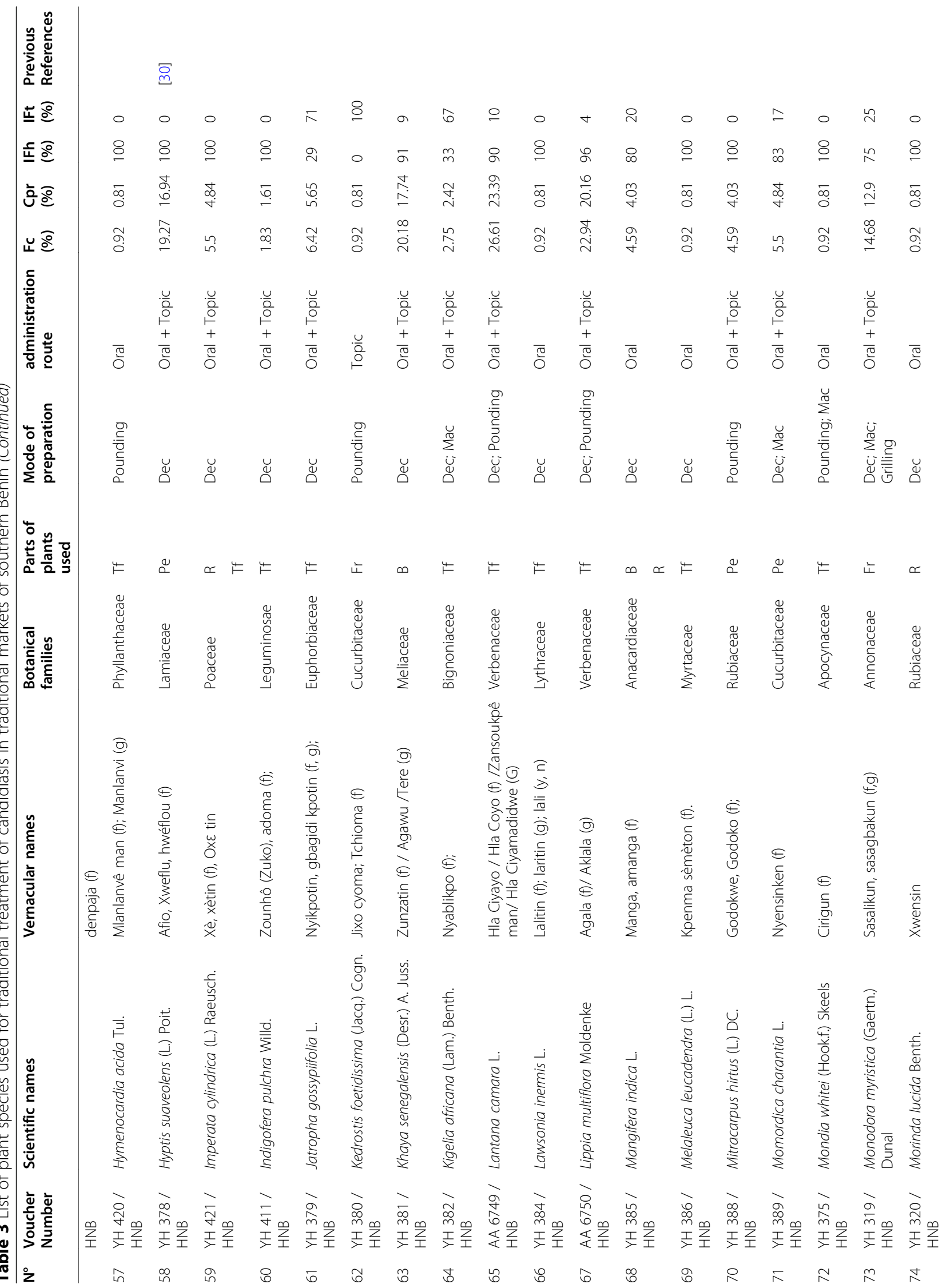




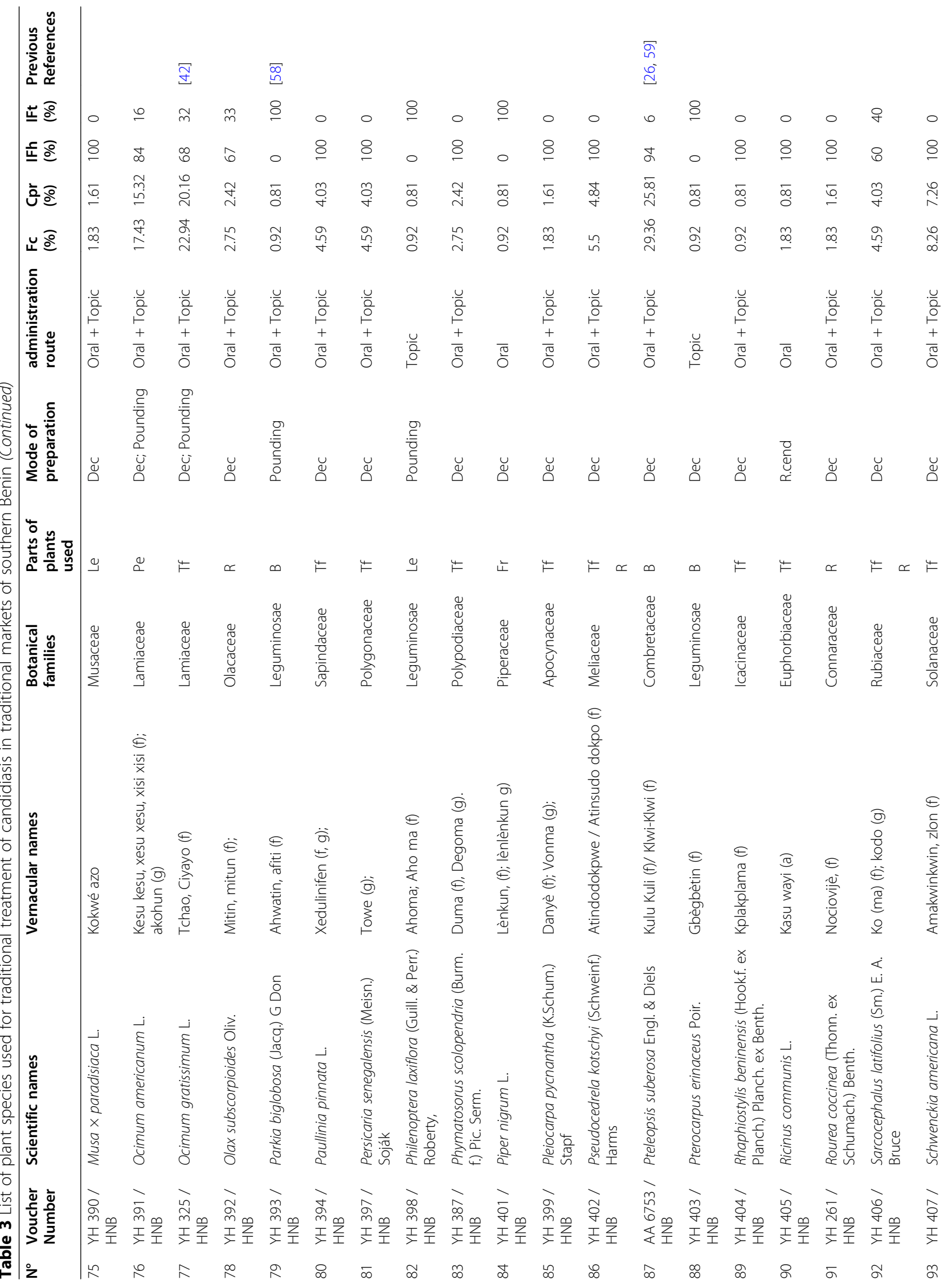




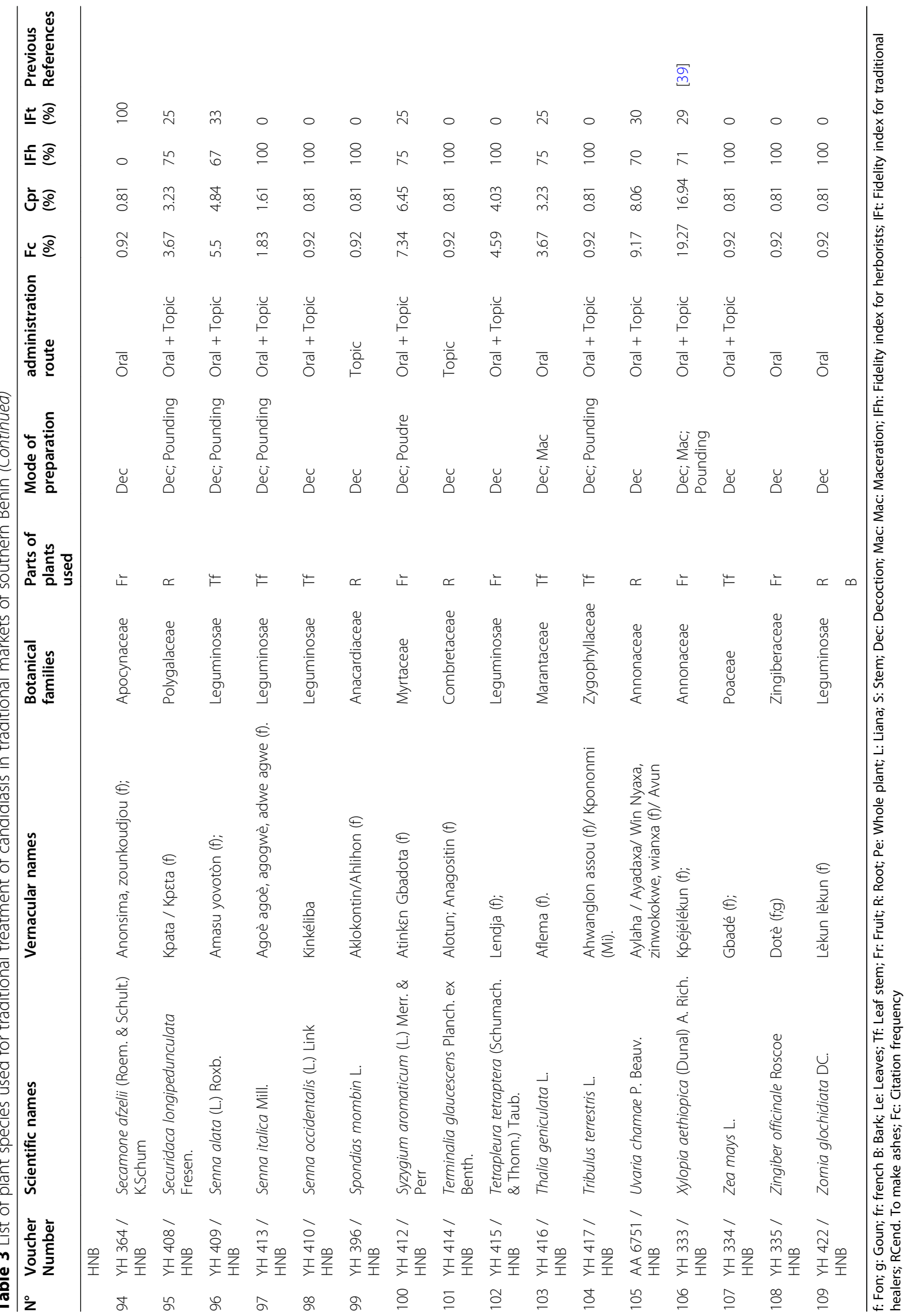




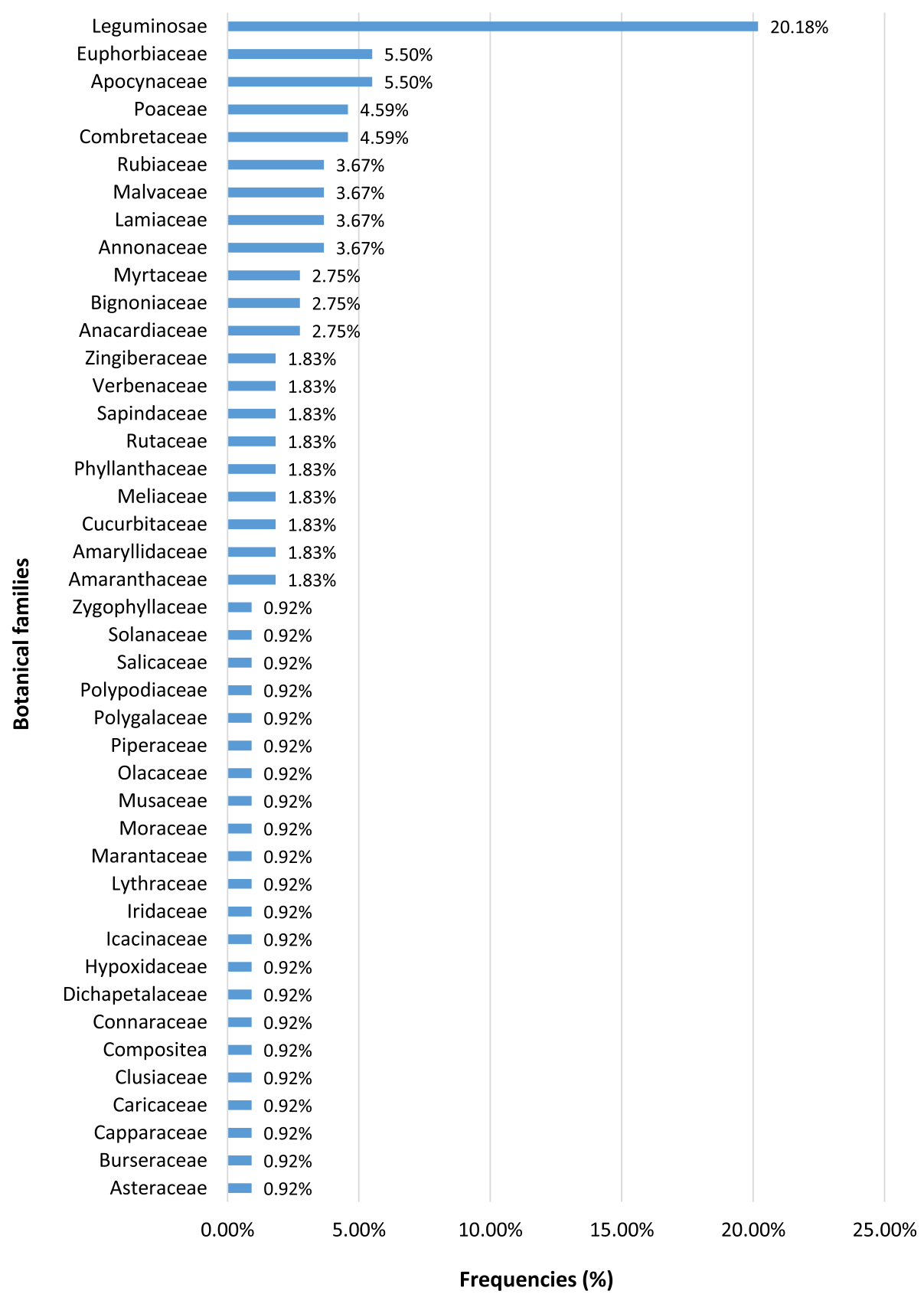

Fig. 6 Distribution of botanical families

especially among traditional healers would have a stabilizing role.

Many studies showed that in practice, decoction was the most common method of preparing herbal recipes often indicated by traditional healers. Indeed, in Benin, the recent work of Koudokpon et al. (2017) on plants used in the treatment of infections and that of Fah et al. had reached the same conclusions $[67,68]$. In other area in Africa, several authors in Togo, Nigeria, Congo and
South Africa had also found that decoction was the most common preparation method used by traditional healers [62, 54, 70, 71]. Kinda et al. (2017) reports that this method is the most efficient way to extract bioactive compounds from plants [72]. This may explain why many traditional healers use it most often.

The oral administration of the preparations was the preparation method, the most recommended way of administration. According to many other authors, it is also 


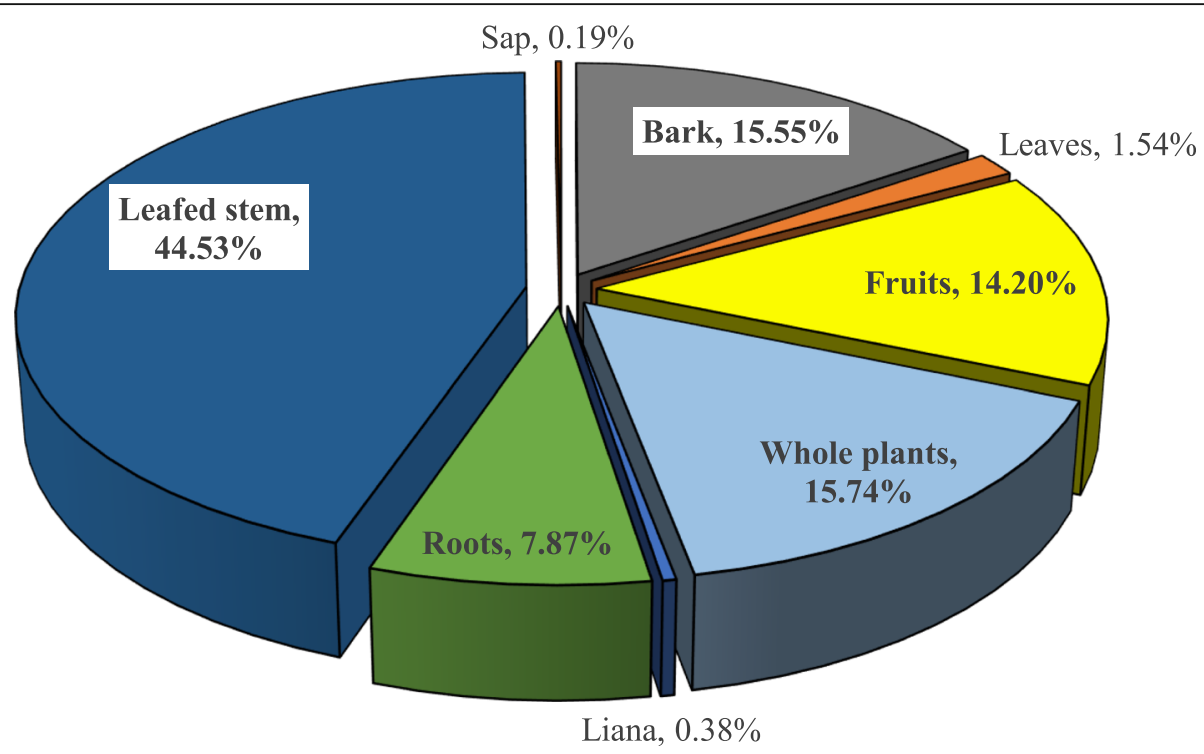

Fig. 7 Plant parts involved in recipes

the route of administration for most herbal preparations both in our study area [61, 67] and in other countries [70, 71, 73-75].

The very low degree of Informant Consensus Factor (ICF) in this study could be justified by the difference in the composition of the recipes served. The diversity of single species cited, often involved in the recipes provided, and could justify this weak consensus. This could also be related to socio-cultural factors. Since the populations of southern Benin are of different ethnic groups and cultures, endogenous practices regarding the use of medicinal plants could be different. Indeed, several ethnic groups were met during the survey. These include: Aïzo (Atlantic Department); Fons (Littoral and Zou Departments); Idaasha, Ifè, Isha (Collines Department); Mahi (Zou and Collines Departments); Goun, Yoruba (Ouémé and Plateau Department); Adja (Mono and Couffo Departments). Some authors who have worked in the same geographical area found the inhabitants belonging to different socio-cultural groups [76-78]. This study therefore shows that Benin is home for a wide variety of medicinal plant species used in the treatment of candidiasis.

The botanical families most cited in this work (Leguminosae, Euphorbiaceae, Apocynaceae and Combretaceae) were similar to those obtained by Koudokpon et al. (2017) who, in their studies on plants used in the treatment of infections pointing out that Leguminosae species were predominant in the recorded species $[45,79]$; candidiasis being infections due to Candida yeasts. However, other researchers in Africa found species belonging the Fabaceae family the most represented [64, 70]. This could be related first to geographical conditions (nature of soils, climatic and other factors) that did not always favor the growth of the same plant species on different soil types and having then a significant influence on bioactive compounds, but also to socio-cultural factors [63]. Since knowledge on the therapeutic use of plants was often transmitted from one generation to another, the plants indicated in the treatment of a disease may also differ from one location to another or from one ethnic group to another.

Since few ethnobotanical surveys on candidiasis were specifically carried out, our results on the plant organs used was similar to those of many recent studies on plants with antimicrobial properties [68, 79]. However, unlike many plant studies, Kinda et al.(2017) found in an ethnobotanical survey of plants used in neuropsychiatric disorders that plant roots were the most commonly used by traditional healers [72].

The frequent involvement of leafy stems in recipes could be explained by the fact that the phytochemical compounds responsible for antifungal effects are more concentrated in these plant organs than others. Chemical groups are reported to be more abundant in this plant organs, where secondary metabolites are synthesized [79]. Castillo et al. reported that terpenes, tannins, flavonoids, essential oils, alkaloids, lecithin and polypeptides are the chemical compounds with antifungal properties in plants [80]. These properties observed with coriander essential oil on Candida spp. strains are reported by Freires et al. to be related to monoterpenes and sesquiterpenes present in the leaves of this plant [81]. In addition, ethnobotanical surveys conducted in Benin on medicinal plants sold in Benin have shown that leaf stems are the most commonly used plant organs by 
medicinal plant sellers, that decoction is the most recommended method of preparation by traditional practitioners and that the oral route is the most commonly used for the administration of medicinal plant recipes $[57,69]$. Among plants identified in this survey, nine are previously cited. These ones are: Allium sativum L. [55]; Catharanthus roseus (L.) G.Don [31]; Cymbopogon citratus (DC.) Stapf (79); Garcinia kola Heckel [55]; Hyptis suaveolens (L.) Poit [30].; Ocimum gratissimum L. [42], Parkia biglobosa (Jacq.) G Don [58]; Pteleopsis suberosa Engl. \& Diels [26, 59]; Xylopia aethiopica (Dunal) A. Rich [39].

Among the 109 medicinal plants species identified in the treatment of candidiasis in southern Benin, 7 species are listed as near threatened plants on the IUCN red list. This confirms the anthropogenic pressure exerted on plant resources and raises the question of plant conservation. Indeed, as shown by Djégo et al. (2011), in Benin, deforestation leads to the disappearance of several medicinal plants [42]. It is therefore important to sensitize the populations on the conservation of plant biodiversity in order to guarantee access to medicinal plants for future generations.

\section{Conclusion}

This current ethnobotanical study showed that South Benin is an overflowing area with many species of medicinal plants indicated the traditional treatment of candidiasis. Market herbalists and traditional healers have indicated 109 medicinal plants in the treatment of candidiasis. The most used species are $P$. suberosa, $L$. camara, C. cinereum, O. gratissimum and L. multiflora.

The various species identified could be new sources of bioactive molecules. However, this requires further pharmacological and toxicological studies.

This study could be very useful to scientists for further research works in order to investigate experimentally the properties of the plant species thus identified to effectively inhibit or even kill Candida strains involved in candidiasis. It could also be extended to the whole country in order to have a single database of medicinal plants used in the treatment of candidiasis.

\section{Supplementary information}

Supplementary information accompanies this paper at https://doi.org/10. 1186/s12906-020-03080-6.

Additional file 1.

\section{Acknowledgements}

We certainly could not have carried out this study without the precious collaboration of our informants, it is about the herbalists of the markets and the herbals traditional. We show them our deepest gratitude and here we praise their frank and kind collaboration.

\section{Authors' contributions}

BAF and JRK participated in all stages of the production of this article. FL and DV provided the scientific direction of the works. LF, CHK and GT participated in the survey. All authors participated in reading and editing the manuscript. The authors read and approved the final manuscript.

\section{Funding}

No funding was obtained for this study.

\section{Availability of data and materials}

The datasets used and/or analysed during the current study available from the corresponding author on reasonable request.

\section{Ethics approval and consent to participate}

The study is part of a thesis. The committee of the "Ecole Doctorale Science de la Vie et de la Terre (ED-SVT) of the University of Abomey-Calavi (UAC) under the number 10185509 has authorized it and obtaining verbal consent from the participants. This choice is justified by the fact that the study population consists mainly of illiterates. To obtain participant consent, study information's were presented to participants in their local languages. And if necessary, answers were given to all their questions. Then, each participant gave his verbal consent which was recorded and archived.

\section{Consent for publication}

Not applicable.

\section{Competing interests \\ No conflict of interest.}

\section{Author details}

'Unité de Recherche en Microbiologie Appliquée et Pharmacologie des substances naturelles (URMAPha), Laboratoire de Recherche en Biologie Appliquée (LARBA), Ecole Polytechnique d'Abomey-Calavi (EPAC), Université d'Abomey-Calavi, 01BP2009 Cotonou, Bénin. ${ }^{2}$ Ecole Normale Supérieure de Natitingou, Université Nationale des Sciences, Technologie, Ingénierie et Mathématiques, BP72 Natitingou, Benin. ${ }^{3}$ Centre de Recherche Enthomologique de Cotonou (CREC), Cotonou, Benin.

Received: 31 October 2019 Accepted: 13 September 2020

Published online: 21 September 2020

\section{References}

1. Cissé MT. Morbidité et mortalité parasitaire et fongique dans les services de médecine interne et maladies infectieuses et tropicales du CHU Point G; 2011

2. Otašević S, Momčilović S, Golubović M, Ignjatović $A$, Rančić $N$, Đorđević $M$, et al. Species distribution and epidemiological characteristics of superficial fungal infections in southeastern Serbia. Mycoses. 2019:62(5):458-65.

3. Sardi JCO, Bernardi T, Scorzoni L, Fusco-Almeida AM, Giannini MMJS. Candida species: current epidemiology, pathogenicity, biofilm formation, natural antifungal products and new therapeutic options. J Med Microbiol. 2013:62(1):10-24.

4. Gonçalves B, Ferreira C, Alves CT, Henriques M, Azeredo J, Silva S. Vulvovaginal candidiasis: epidemiology, microbiology and risk factors. Crit Rev Microbiol. 2016:42(6):905-27.

5. Kapila S, Goel S, Prakash A. Identification of Candida species in neonatal septicaemia. Int J Contemp Pediatr. 2006;3(2):601-5.

6. Pristov KE, Ghannoum MA. Resistance of Candida to azoles and echinocandins worldwide. Clin Microbiol Infect. 2019:25(7):792-8.

7. Deorukhkar SC, Saini S. Why Candida species have emerged as important nosocomial pathogens? Int J Curr Microbiol App Sci. 2016;5(1):533-45.

8. Geddes-McAlister J, Shapiro RS. New pathogens, new tricks: emerging, drug-resistant fungal pathogens and future prospects for antifungal therapeutics: drug-resistant fungal pathogens. Ann N Y Acad Sci. 2019; 1435(1):57-78.

9. Segal E, Frenkel M. Experimental in vivo models of candidiasis. J Fungi. 2018:4(1):21

10. Sacarlal J, Denning D. Estimated burden of serious fungal infections in Mozambique. J Fungi. 2018;4(3):75.

11. Caggiano G, Montagna MT. Fungal Infections in Patients of Paediatric Age. In: Özdemir Ö, Özdemir Ö, editors. Contemporary Pediatrics; 2012. p. 434. 
(InTech). Available from: www.intechopen.com/books/contemporarypediatrics/fungal-infections-in-patients-of-pediatric-age.

12. Bongomin F, Gago S, Oladele R, Denning D. Global and multi-National Prevalence of fungal diseases_estimate precision. J Fungi. 2017;3(4):57.

13. Brown GD, Denning DW, Gow NAR, Levitz SM, Netea MG, White TC. Hidden Killers: Human Fungal Infections. Sci Transl Med. 2012;4(165):165rv13.

14. GATTI GAFFFI. Global fungal infection forum III: Essential diagnostics for advanced HIV disease and serious fungal infections. Kampala: GATTI; 2018. p. 52

15. Institut P. Lettre de l'institut Pasteur $n^{\circ} 72 ; 2011$.

16. Alangaden GJ. Nosocomial fungal infections: epidemiology, infection control, and prevention. Infect Dis Clin N Am. 2011;25(1):201-25.

17. Perlroth J, Choi B, Spellberg B. Nosocomial fungal infections: epidemiology, diagnosis, and treatment. Med Mycol. 2007;45(4):321-46.

18. Cortegiani A, Misseri G, Fasciana T, Giammanco A, Giarratano A, Chowdhary A. Epidemiology, clinical characteristics, resistance, and treatment of infections by Candida auris. J Intensive Care. 2018:6(1) Available from: https://jintensivecare.biomedcentral.com/articles/10.1186/s40560-018-0342-4. Cited 2019 May 27.

19. Thomaz DY, de Almeida JN, Lima GME, de Oliveira NM, Camargo CH, de Carvalho GR, et al. An Azole-Resistant Candida parapsilosis Outbreak: Clonal Persistence in the Intensive Care Unit of a Brazilian Teaching Hospital. Front Microbiol. 2018:9 Available from: https://www.frontiersin.org/article/10.3389/ fmicb.2018.02997/full. Cited 2019 May 27.

20. Dellière $S$, Healey K, Gits-Muselli M, Carrara B, Barbaro A, Guigue N, et al. Fluconazole and Echinocandin Resistance of Candida glabrata Correlates Better with Antifungal Drug Exposure Rather than with MSH2 Mutator Genotype in a French Cohort of Patients Harboring Low Rates of Resistance. Front Microbiol. 2016;7 Available from: http://journal.frontiersin.org/article/1 0.3389/fmicb.2016.02038/full. Cited 2019 May 27.

21. Peron IH, Reichert-Lima F, Busso-Lopes AF, Nagasako CK, Lyra L, Moretti ML, et al. Resistance Surveillance in Candida albicans: A Five-Year Antifungal Susceptibility Evaluation in a Brazilian University Hospital. PLoS One. 2016; 11(7):e0158126 Nielsen K, editor.

22. Whaley SG, Berkow EL, Rybak JM, Nishimoto AT, Barker KS, Rogers PD. Azole Antifungal Resistance in Candida albicans and Emerging Non-albicans Candida Species. Front Microbiol. 2017;7 Available from: http://journal. frontiersin.org/article/10.3389/fmicb.2016.02173/full. Cited 2019 May 27.

23. Kawsud P, Puripattanavong J, Teanpaisan R. Screening for Anticandidal and Antibiofilm activity of some herbs in Thailand. Trop J Pharm Res. 2014;13: 1495.

24. Armstrong-James $D$, Meintjes $G$, Brown GD. A neglected epidemic: fungal infections in HIV/AIDS. Trends Microbiol. 2014;22(3):120-7.

25. Bassetti M, Righi E, Montravers P, Cornely OA. What has changed in the treatment of invasive candidiasis? A look at the past 10 years and ahead. Antimicrob Chemother. 2018;73(suppl_1):i14-25.

26. Gbogbo KA, Agban A, Woegan YA, Amana EK, Hoekou PY, Batawila K, et al. Evaluation de l'activité antimicrobienne de Momordica charantia (Curcubitaceae); Psidium guajava (Myrtaceae) et Pteleopsis suberosa (Combretaceae). Eur Sci J. 2013;9(36):411-21.

27. Lifongo LL, Simoben CV, Ntie-Kang F, Babiaka SB, Judson PN. A bioactivity versus Ethnobotanical survey of medicinal plants from Nigeria. West Africa Nat Prod Bioprospecting. 2014;4(1):1-19.

28. Phumthum M, Srithi $K$, Inta A, Junsongduang A, Tangjitman $K$, Pongamornkul W, et al. Ethnomedicinal plant diversity in Thailand. J Ethnopharmacol. 2018;214:90-8.

29. Li F-S, Weng J-K. Demystifying traditional herbal medicine with modern approach. Nat Plants. 2017;3(8):17109.

30. Agban A, Atchou K, Tchacondo T, Hoekou YP, Batawila K, De Souza C. Potentiel antimicrobien des extraits de feuilles d'Hyptis suaveolens poit. J Rech Sci L'Université Lomé. 2013;15(3):37-44.

31. Akpotu MO, Eze PM, Abba CC, Umeokoli BO, Nwachukwu CU, Okoye FB, et al. Antimicrobial activities of secondary metabolites of endophytic fungi isolated from Catharanthus roseus. J Health Sci. 2017;7(1):15-22.

32. Dro B, Soro D, Koné MW, Bakayoko A, Kamanzi K. Evaluation de l'abondance de plantes médicinales utilisées en médecine traditionnelle dans le Nord de la Côte d'Ivoire. J Anim Plant Sci. 2013;17(3):2631-46.

33. Sofowora A, Ogunbodede E, Onayade A. The role and place of medicinal plants in the strategies for disease prevention. Afr J Tradit Complement Altern Med. 2013;10(5) Available from: http://www.ajol.info/index.php/ ajtcam/article/view/92333. Cited 2019 Jun 10.
34. Jamshidi-Kia F, Lorigooini Z, Amini-Khoei H. Medicinal plants: past history and future perspective. J Herbmed Pharmacol. 2018;7(1):1-7.

35. Tantary S, Masood A, Bhat AH, Dar KB, Zargar MA, Ganie SA. In vitro antioxidant and RBC membrane stabilization activity of Euphorbia wallichii. Free Radic Antioxid. 2016;7(1):13-22.

36. Chaitanya Kolluru V, Agrawal P, Kotagir D. Comparative Analysis of Antimicrobial Activity of Herbal Extracts against Pathogenic Microbes. Curr Trends Biomed Eng Biosci. 2018;16(1) Available from: https:// juniperpublishers.com/ctbeb/CTBEB.MS.ID.555930.php. Cited 2019 Aug 19.

37. Boakye YD, Agyare C, Hensel A. Anti-infective properties and time-kill kinetics of Phyllanthus muellerianus and its major constituent, geraniin; 2016.

38. Pawar BT. Antifungal activity of some stem extracts against seed-borne pathogenic fungi. J Phytol. 2011;3(12):49-5.

39. Sessou P, Souaïbou F, Jean-Pierre N, Brice F, Paulin A, Issaka Y, et al. Chemical composition and in vitro antifungal activity of Zingiber officinale essential oil against foodborne pathogens isolated from a traditional cheese wagashi produced in Benin. Int J Biosci. 2012;2(9):20-8.

40. Yaye YG, KRA AKM, ACKAH JAAB, Djaman AJ. ÉVALUATION DE L'ACTIVITÉ ANTIFONGIQUE ET ESSAI DE PURIFICATION DES PRINCIPES ACTIFS DES EXTRAITS DE Terminalia mantaly (H. Perrier), UNE COMBRETACÉE, SUR LA CROISSANCE in vitro DE Candida albicans. ASSESSMENT OF THE ANTIFUNGAL ACTIVITY AND TEST OF ACTIVE PRINCIPLE PURIFICATION OF EXCERPT OF Terminalia mantaly (H. PERRIER), A COMBRETACEAE, ON THE in vitro GROWTH OF Candida albicans. Bull Société R Sci Liège. 2011;80:953-64.

41. Agban A, Gbogbo KA, Amana EK, Tegueni K, Batawila K, Kossi K, et al. Evaluation de l'activité antimicrobienne de Tridax procumbens (Asteraceae); Jatropha multifida (Euphorbiaceae) et de Chromolaena odorata (Asteraceae). Eur Sci J. 2013;9(36):278-90.

42. Djègo J, Djego-Djossou S, Cakpo Y, Agnani P, Sinsin B. Evaluation du potentiel ethnobotanique des populations rurales au Sud et au centre du Bénin. Int J Biol Chem Sci. 2011;5(4):1432-47.

43. Lagnika L, Amoussa AMO, Adjileye RAA, Laleye A, Sanni A. Antimicrobial, antioxidant, toxicity and phytochemical assessment of extracts from Acmella uliginosa, a leafy-vegetable consumed in Bénin, West Africa. BMC Complement Altern Med. 2016;16(1):34.

44. Klotoé JR, Dougnon TV, Koudouvo K, Atègbo J-M, Loko F, Akoègninou A, et al. Ethnopharmacological survey on Antihemorrhagic medicinal plants in south of Benin. Eur J Med Plants. 2013;3(1):40-51.

45. Koudokpon H, Dougnon TV, Bankolé HS, Fah L, Hounmanou YMG, BabaMoussa $L$, et al. Ethnobotanical survey of plants used in the treatment of infections in southern Benin. Health Sci Dis. 2017;18(2):92-9.

46. Mpondo Mpondo E, Dibong SD. Traditional knowledge on medicinal plants use by ethnic communities in Douala, Cameroon. Eur J Med Plants. 2012; 2(2):159.

47. Briguiche H, Zidane L. Ethnobotanical study of medicinal plants from ElJadida City (Morocco)/Estudio etnobotánico de las plantas medicinales de la ciudad de El-Jadida (Marruecos). Lazaroa. 2016;37:1.

48. Akoègninou $A$, van der Burg WJ, van der Maesen $L G$, Adjakidjè $V$, Essou JP, Sinsin B, et al. Flore analytique du Bénin. In: Wageningen University papers, vol. 06. Pays-Bas: Backhuys Publishers; 2006. p. 1064.

49. Shalukoma C, Bogaert J, Duez P, Stévigny C, Pongombo C, Visser M. Les plantes médicinales de la région montagneuse de Kahuzi-Biega en République Démocratique du Congo: utilisation, accessibilité et consensus des tradipraticiens. Bois For Trop. 2014;326:43-55.

50. Zougagh S, Belghiti A, Rochd T, Zerdani I, Mouslim J. Medicinal and aromatic plants used in traditional treatment of the Oral pathology: the Ethnobotanical survey in the economic capital Casablanca, Morocco (North Africa). Nat Prod Bioprospecting. 2019;9(1):35-48.

51. Alsarhan A, Sultana N, Kadir MRA, Aburjai T. Ethnopharmacological survey of medicinal plants in Malaysia, the Kangkar Pulai region. Int J Pharmacol. 2012;8(8):679-86.

52. Lougbegnon TO, Gbesso F, Logbo J, Tente B, Codjia JTC. Ethnobotanical study of plants with therapeutic value in the commune of Glazoué in Benin (West Africa). Int J Innov Appl Stud. 2018;24(2):644-55.

53. Ambe AS, Ouattara D, Tiebre M-S, Vroh BTA, Zirihi GN, N'guessan KE. Diversité des plantes médicinales utilisées dans le traitement traditionnel de la diarrhée sur les marchés d'Abidjan (Côte d'Ivoire). J Anim Plant Sci. 2015; 26(2):4081-96.

54. Bade FT, Maliki M, Allagbe, Dah-Nouvlessounon D, Nabede A, Assogba S, et al. Ethnobotanical Survey of Three Species of Desmodium genus 
(Desmodium ramosissimum, Desmodium gangeticumandDesmodium adscendens) Used in Traditional Medicine, Benin. Int J Therm Sci. 2018;7:12.

55. Ezeifeka GO, Mbata TI, Patrick AO. Antimicrobial activities of Cajanus cajan, Garcinia cola and Xylopia aetiopica on pathogenic microorganisms. Biotechnology. 2004;3(1):41-3.

56. Carmo ES, Pereira F de O, Cavalcante NM, Gayoso CW, Lima E de O. Treatment of pityriasis versicolor with topical application of essential oil of Cymbopogon citratus (DC) Stapf - therapeutic pilot study. An Bras Dermatol. 2013 Jun;88(3):381-5.

57. Adomou AC, Yedomonhan H, Djossa B, Legba Sl, Oumorou M, Akoegninou A. Etude Ethnobotanique des plantes médicinales vendues dans le marché d'Abomey-Calavi au Bénin. Int J Biol Chem Sci. 2012;6(2):745-72.

58. Chaumont J-P, Mandin D, Sanda K, Koba K, de Souza CA. Activités antimicrobiennes in vitro de cinq huiles essentielles de Lamiacées togolaises vis-àvis de germes représentatifs de la microflore cutanée. Acta Bot Gallica. 2001 Jan;148(2):93-101.

59. Mgbeahuruike EE, Holm Y, Vuorela H, Amandikwa C, Fyhrquist P. An ethnobotanical survey and antifungal activity of Piper guineense used for the treatment of fungal infections in West-African traditional medicine. J Ethnopharmacol. 2019 Jan 30;229:157-66.

60. Dassou HG, Ogni CA, Yédomonhan H, Adomou AC, Tossou M, Dougnon JT, et al. Diversité, usages vétérinaires et vulnérabilité des plantes médicinales au Nord-Bénin. Int J Biol Chem Sci. 2014;8(1):189-210.

61. Agbankpé AJ, Dougnon TV, Bankolé HS, Yèhouénou B, Yédomonhan H, Lègonou $\mathrm{M}$, et al. Etude ethnobotanique des légumes feuilles thérapeutiques utilisés dans le traitement des diarrhées au sud-Bénin (Afrique de l'Ouest). Int J Biol Chem Sci. 2014;8(4):1784-95.

62. Odoh UE, Uzor PF, Eze CL, Akunne TC, Onyegbulam CM, Osadebe PO. Medicinal plants used by the people of Nsukka local government area, South-Eastern Nigeria for the treatment of malaria: an ethnobotanical survey. J Ethnopharmacol. 2018;218:1-15.

63. Laleye FOA, Mensah S, Assogbadjo AE, Ahissou H. Diversity, knowledge, and use of plants in traditional treatment of diabetes in the Republic of Benin. Ethnobot Res Appl. 2015;14:231-57.

64. Masevhe NA, McGaw LJ, Eloff JN. The traditional use of plants to manage candidiasis and related infections in Venda. South Africa. J Ethnopharmacol. 2015;168:364-72

65. Dougnon TV, Attakpa E, Bankolé H, Hounmanou YMG, Dèhou R, Agbankpè $J$, et al. Etude ethnobotanique des plantes médicinales utilisées contre une maladie cutanée contagieuse: La gale humaine au Sud-Bénin. Pharmacopée Médecine Tradit Afr. 2016;18:16-22.

66. Mugisha MK, Asiimwe S, Namutebi A, Borg-Karlson A-K, Kakudidi EK. Ethnobotanical study of indigenous knowledge on medicinal and nutritious plants used to manage opportunistic infections associated with HIV/AIDS in western Uganda. J Ethnopharmacol. 2014;155(1):194-202.

67. Fah L, Klotoé JR, Dougnon TV, Koudokpon H, Fanou VBA, Dandjesso C, et al. Étude ethnobotanique des plantes utilisées dans le traitement du diabète chez les femmes enceintes à Cotonou et Abomey-Calavi (Bénin). J Anim Plant Sci. 2013;18(1):2647-58.

68. Koudokpon H, Dougnon T, Bankolé H, Fah L, Hounmanou Y, Loko F. Enquête ethnobotanique sur les plantes utilisées dans le traitement des infections au sudbénin. Health Sci Dis. 2017;18:92-9.

69. Klotoe JR, Koudouvo K, Ategbo J-M, Dandjesso C, Dougnon V, Loko F, et al. Medicinal plants sold as anti-Haemorrhagic in the Cotonou and AbomeyCalavi markets (Benin). Int J Biol. 2018;10(1):17.

70. Alfa T, Anani K, Adjrah Y, Batawila C, Ameyapoh Y. Ethnobotanical survey of medicinal plants used against Fungallnfections in prefecture of Sotouboua central Region. Togo Eur Sci J. 2018;14(3):342-57.

71. Ngbolua K, Inkoto C, Mongo N, Ashande C, Masens Y, Mpiana P. Étude ethnobotanique et floristique de quelques plantes médicinales commercialisées à Kinshasa, République Démocratique du Congo. Rev Mar Sci Agron Vét. 2019;7(1):118-28

72. Kinda PT, Zerbo P, Guenné S, Compaoré M, Ciobica A, Kiendrebeogo M. Medicinal plants used for neuropsychiatric disorders treatment in the Hauts Bassins region of Burkina Faso. Medecines. 2017:4(32):1-21 Avalable from: https:/www.ncbi.nlm.nih.gov/pmc/articles/PMC5590068/.

73. Gbadamosi IT, Egunyomi A. Ethnobotanical survey of plants used for the treatment and Management of Sexually Transmitted Infections in Ibadan, Nigeria. Ethnobot Res Appl. 2014;12:659-69.
74. Lawin IF, Lalèyè OAF, Agbani OP, Assogbadjo AE. Ethnobotanical assessment of the plant species used in the treatment of diabetes in the Sudano-Guinean zone of Benin. J Anim Plant Sci. 2015;26(3):4108-23.

75. Ohemu TL, Agunu A, Olotu PN, Ajima U, Dafam DG, Azila JJ. Ethnobotanical survey of medicinal plants used in the traditionaltreatment of viral infections in Jos, plateau state, Nigeria. Int J MedArom Plants. 2014;4(2):7481.

76. Agoyi EE, Assogbadjo AE, Gouwakinnou G, Okou FAY, Sinsin B. Ethnobotanical assessment of Moringa oleifera lam. In southern Benin (West Africa). Ethnobot Res Appl. 2014;12(i):551-61.

77. Loko LEY, Toffa J, Adjatin A, Akpo AJ, Orobiyi A, Dansi A. Folk taxonomy and traditional uses of common bean (Phaseolus vulgaris L.) landraces by the sociolinguistic groups in the central region of the Republic of Benin. J Ethnobiol Ethnomed. 2018;14(1) Available from: https://ethnobiomed. biomedcentral.com/articles/10.1186/s13002-018-0251-6. Cited 2019 May 3.

78. Onzo FC, Azokpota P, Akissoe N, Agbani OP. Biodiversité des emballagesfeuilles végétales utilisées dans l'artisanat agroalimentaire au Sud du Bénin. J Appl Biosci. 2013;72:5810-21.

79. Dougnon TV, Attakpa E, Bankolé HS, Hounmanou YMG, Dèhou R, Agbankpè $\mathrm{J}$, et al. Etude ethnobotanique des plantes médicinales utilisées contre une maladie cutanée contagieuse : La gale humaine au Sud-Bénin. Rev Cames Pharm Méd Trad Afr. 2016;16(1):16-22.

80. Castillo F, Hernández D, Gallegos G, Rodríguez R, Aguilar CN. Antifungal Properties of Bioactive Compounds from Plants. In: Fungicides for Plant and Animal Diseases: Dharumadurai Dhanasekaran; 2012. p. 298. (InTech). Available from: www.intechopen.com/books/fungicides-for-plant-andanimal-diseases/antifungal-properties-of-bioactivecompounds-from-plants.

81. de Almeida FI, Murata RM, Furletti VF, Sartoratto A, de Alencar SM, Figueira GM, et al. Coriandrum sativum L. (Coriander) Essential Oil: Antifungal Activity and Mode of Action on Candida spp., and Molecular Targets Affected in Human Whole-Genome Expression. PLoS One. 2014;9(6):e99086 Mylonakis E, editor.

\section{Publisher's Note}

Springer Nature remains neutral with regard to jurisdictional claims in published maps and institutional affiliations.

Ready to submit your research? Choose BMC and benefit from

- fast, convenient online submission

- thorough peer review by experienced researchers in your field

- rapid publication on acceptance

- support for research data, including large and complex data types

- gold Open Access which fosters wider collaboration and increased citations

- maximum visibility for your research: over $100 \mathrm{M}$ website views per year

At $\mathrm{BMC}$, research is always in progress.

Learn more biomedcentral.com/submissions 